\title{
Strategi Komunikasi Public Relation Dalam Membangun Citra Dan Kepercayaan Calon Jemaah Haji dan Umroh
}

\section{The Role of the Social Service in Dealing with the Problem of Social Violence Against Children in North Sumatra Province}

\author{
Ismaulidina*, Effiati Juliana Hasibuan \& Taufik Wal Hidayat \\ Program Studi Ilmu Komunikasi, Fakultas Ilmu Sosial dan Ilmu Politik \\ Universitas Medan Area, Indonesia
}

\begin{abstract}
Abstrak
Peneilitan ini bertujuan untuk meneliti strategi komunikasi public relation dalam membangun citra dan kepercayaan calon Jemaah haji dan umroh di PT. Siar Tour Medan. Dilatar belakangi karena penyelenggaraan ibadah haji dan umroh selama ini di nilai kurang efektif dan efisien. Hal ini turut mempengaruhi kualitas pemberian pelayanan dan perlindungan pada jamaah sehingga tingkat kepercayaan dan citra perusahaan berkurang dimata pelanggan. Metode penelitian yang digunakan adalah kualitatif dengan menggunakan teknik analisis deskriptif. Teori yang digunakan dalam penelitian ini adalah teori Public Realtion oleh RUSLAN yang disingkat dengan PENCILS dan citra yang dibentuk melalui empat komponen menurut Soleh Soemirat dan Elvinaro Ardianto dalam buku dasardasar Public Relation yaitu, persepsi, kognisi, motivasi dan sikap.
\end{abstract}

Kata Kunci: Strategi komunikasi, Public Relation, Membangun citra dan kepercayaan

\begin{abstract}
The Purpose of this tudy is to study public communication strategy to build image and trust of prospective Jemaah hajj and umroh at PT. Siar Tour Medan. This study has been motivated because the implementation of the hajj and umroh so far ineffectice and inefficient. It has influenced service quality to customers. Methode that used in this stdy is qualitative and used descriptive analysis technique. This study used public relation by RUSLAN Theory known as PENCILS and the image that created through fourth components explain by SOleh Soemirat and Elvinaro Ardianto in the book dasar-dasar Public Relation such as perception, cognition, motivation and attitude.
\end{abstract}

Keywords: Communication Strategy

How to Cite: Ismaulidina. Hsb, Effiati Juliana. \& Hidayat, Taufik Wal. (2020). Strategi Komunikasi Public Relation Dalam Membangun Citra Dan Kepercayaan Calon Jemaah Haji dan Umroh. Jurnal Ilmu Pemerintahan, Administrasi Publik dan Ilmu Komunikasi (JIPIKOM), 2(1) 2020: 12-17

*E-mail: ismaulidina@gmail.com

ISSN 2550-1305 (Online) 


\section{PENDAHULUAN}

Kegiatan ibadah haji dan umrah mempunyai dua sisi yang harus diperhatikan dalam pelaksanaannya yaitu, standar pelaksanaannya saat masih di tanah air banyak aspek penting yang harus diperhatikan pembinaannya seperti dalam pelayanan jasa (pembayaran setoran ONH ke bank, pengurusan dokumen haji dan umrah, pemeriksaan kesehatan calon jemaah), bimbingan manasik (materi bimbingan, metode dan waktu bimbingan), penyediaan perlengkapan, dan konsultasi keagamaan. Sedangkan standar pelayanan ibadah haji dan umrah di tanah suci adalah akomodasi, transportasi, konsumsi, serta kesehatan. Pada tahun 2012 jumlah Jemaah umroh dari Indonesia sekitar 260.000 jemaah. Hal ini meningkat drastis dari tahun 2011 yang hanya berjumlah 180.000 jemaah dan pada tahun 2013 berjumlah 280.000 jemaah. Penyajian dan usaha untuk meraih peminat dari konsumen dan masyarakat tidak terlepas dari usaha strategi yang mengkomunikasikan dan mempublikasikan kelebihan-kelebihan dan produk perusahaan tersebut dengan baik agar dierima oleh khalayak. (Hasibuan \& Indra).

Baik strategi manajemen dibidang pelayanan, penyuluhan, dan sebagainya. Sehingga apa yang menjadi tujuan dalam membangun citra dan kepercayaan calon Jemaah haji dan umroh tercapai dengan baik. Adanya peningkatan jumlah Jemaah tidak terlepas dari peran public relations dalam membangun citra dan kepercayaan masyarakat. Karena seorang public relations harus dapat mengekspresikan atau mengungkapkan suatu cara pandang atau pikiran tentang suatu produk dan layanan jasa yang dimilikinya. (Waridah, 2016 ). Dalam hal ini seorang public relations harus dapat memberikan suatu citra yang positif kepada para konsumen sehingga menimbulkan asosiasi dan citra yang diinginkan oleh konsumen terhadap suatu produk atau layanan jasa. Melihat perkembangan Jemaah PT. Siar Tour Medan sebagaimana fakta diatas disebabkan karena citra perusahaan yang berkaitan dengan kemampuan perusahaan menjaga nama baik dalam pelayanan Jemaah cukup memuaskan karena perusahaan mampu membangun kesan yang baik bagi masyarakat serta memiliki sikap yang baik dalam melayani konsumen. Sedangkan munculnya kpercayaan masyarakat disebabkan sikap pelayanan yang selalu konsisten terhaap pemberangkatan Jemaah, jujur, bertanggung jawab, harga yang terjangkau serta pelayanan yang ramah.

Dalam kaitannya kegiatan komunikasi, public relations menjalankan komunikasi dengan tujuan untuk meciptakan sebuah efek, yaitu berupa citra perusahaan (corporate image). Menyelenggarakan komunikasi untuk membentuk citra korporasi atau organisasi dimata pihak luar dimaksudkan untuk menumbuhkan rasa saling pengertiaan diantara korporasi atau organisasi dan pihak luar. Bagi korporasi, pihak luar yang dimaksud adalah masyarakat, baik sebagai konsumen, agen, pemasok, atau rekanan korporasi. Saling pengertian antara organisasi dan masyarakat, berkembang meelalui hubungan baik antara keduanya. Hubungan yang baik ini terjadi karena adanya komunikasi yang baik (public relationship). Dari situlah terbentuk citra perusahaan (corporate image) dimata pihak luar. Hal ini tentunya sesuai dengan defenisi public relations berdasarkan tujuan kegiatannya, yaitu humas sebagai aktivitas berkelanjutan untuk menjamin perusahaan memiliki citra yang kuat dimata publik. (Ritonga \& Hasibuan, 2016). 
Strategi adalah rencana yang menyeluruh dan terpadu mengenai kegiatan-kegiatan utama perusahaan yang akan menentukan keberhasilannya untuk mencapai tujuan pokok dalam lingkungan yang penuh tantangan. Suatu strategi terdiri dari beberapa taktik. Strategi bersifat umum, mendasar, dan berjangka panjang dibanding dengan taktik yang merupakan rencana yang lebih khusus, operasional dan berjangka pendek (Siahaan, Hendra \& Matondang, 2017; Panggabean, 2019; Sembiring, 2016). Menurutu Ruslan yang dikutip (Nova, 2009) terdapat 7 strategi public relations atau yang lebih dikenal dengan bauran public relations yang dapat disingkat dengan PENCILS, yaitu: Publication (Publikasi), Event, News (Berita), Community Involvement, Inform or Image, Lobbying and Negotiation (Lobi dan Negosiasi), Social Responsibility (tanggung jawab).

Citra perusahaan merupakan persepsi masyarakat terhadap perusahaan atau produknya (Kotler \& Armstrong, 2008). Citra perusahaan brehubungan dengan nama bisnis, arsitektur, variasi produk, tradisi, iddeologi, dan kesan pada kualitas yng dikomunikasikan oleh setiap karyawan yang berinteraksi dengan klien organisasi. Citra perusahaan dapat berperingkat baik dan dapat berperingkat buruk. Hal tersebut tergantung dari perusahaan bagaiamana menggiring opini publik dalam menilai citra perusahaan. Citra negtatif pada perusahaan dapat mengakibatkan pelanggan menjadi kurang loyal dan tidak ingin kembali menggunakan jasa dan produknya kembali. Sebaliknya, citra prositif sebuah perusahaan dapat menumbuhkan sikap loyal pelanggan terhadap perusahaan dalam bentuk kesediaan pelanggan untuk kembali menggunakan produk atau jasa perusahaan tersebut. Apabila citra dikelola secara efektif, citra dapat melindungi perusahaan dari serangan perusahaan pesaing baru. Untuk membentuk citra yang baik dan kuat diperlukan adanya strategi yang terencana yang dikemas dalam kegiatan upaya perusahaan dalam menggiring publik mempersepsikan apa yang menjadi tujuan dan harapan perusahaan.

Setiap usaha yang dikerjakan perusahaan memiiki tujuan dan tidak sembarangan dalam membuat strategi. Strategi dalam membentuk citra dikategorikan menjadi sangat penting untuk dilakukan. Terutama bagi perusahaan yang bergerak di bidang jasa karena dalam membuat strategi, perusahaan dituntut untuk menilai dari merencanakan, mensosialisasikan, menerapkan, sert mengevaluasi hasil dari strategi yang telah dilaksanakan. Citra perusahaan menjadi salah satu pegangan bagi publik khususnya pelanggan dalam keputusan seperti keputusan membeli suatu barang atau menetukan tempat untuk berkunjung, keputusan untuk memilih jasa travel haji dan umroh dan lainlain. Citra yang baik akan menimbulkan dampak positif bagi perusahaan, sedangkan citra yang buruk melahirkan dampak yang negative dan melemahkan kemampuan perusahaan dalam persaingan (Siahaan, Hendra, \& Matondang, 2017; Syahputra, Hendra, \& Hidayat, 2018; Effendi. Hendra \& Armansyah, 2019).

Kepercayaan (beliefs) adalah pemikiran deskriptif yang dianut seseorang tentang suatu hal. Kepercayaan konsumen terhadap suatu objek adalah jumlah total kepercayaan dan nilai-nilai keseluruhan yang relevan (Kotler \& Armstrong, 2008:117). Kepercayaan lebih mudah diubah melalui usaha-usaha komunikasi pemasaran. , sedangkan mafaat yang diinginkan sifatnya lebih melekat, lebih tahan lama, dan lebih berkaitan dengan 
norma-norma cultural. Indikator kepercayaan sebagaimana dalam hal ini membangun citra dan reputasi yang positif merupakan bentuk rasa percaya konsumen terhadap perusahaan. Karena apabila perusahaan tidak memiliki citra dan reputasi yang baik maka sudah dipastikan bahwa perusahaan tersbut tidak akan bertahan lama bersaing di dunia bisnis. Begitu juga dengan upaya memberikan kualitias pelayanan yang baik dapat membantu meningkatkan atau membangun kepercayaan konsumen terhadap perusahaan.

\section{METODE PENELITIAN}

Metode penelitian yang digunakan dalam penelitian ini adalah pendekatan kualitatif. Metode kualitatif bertujuan untuk menemukan solusi atas suatu masalah dengan langkah-langkah tersebut, siapapun yang menggunakan metode yang sama untuk objek dan subjek yang sama akan diperoleh hasil yang sama pula (Silalahi, 2009). Sumber data diperoleh dari informan kunci yaitu seorang public relations PT.Siar Tour Medan, dan informan tambahan adalah jemaah atau calon jemaah haji dan Umroh PT. Siar Tour Medan. Pengumpulan data dapat dilakukan dalam berbagai setting, sumber dan berbagai cara. Dalam penelitian kualitatif pengumpulan data dilakukan kepada natural setting "kondisi yang alamiah" (Sugiyono, 2006). Penelitian ini menggunakan teknik wawancara mendalam, observasi dan dokumentasi sebagai metode pengumpulan data.

\section{HASIL DAN PEMBAHASAN}

Strategi komunikasi yang dilakukan oleh public relations PT. Siar Tour dalam membangun citra dan kepercayaan calon jemaah haji dan umrah sesuai dengan hasil penelitian yang dilakukan bila dikaitkan dengan konsep dan teori yang ada yaitu melalui Publications (publikasi) Menurut Ruslan yang dikutip oleh (Nova, 2009) terdapat 7 Strategi Public Relations atau yang lebih dikenal dengan bauran public relations yang dapat disingkat menjadi PENCILS yaitu: menyelenggarakan publikasi, merancang sebuah event, membuat press release, mengadakan kontak sosial dengan para calon jemaah, menyebarluaskan informasi melalui berbagai media tentang aktivitas atau kegiatan perusahaan atau organisasi yang perlu diketahui oleh publik. Strategi komunkasi yang dilakukan adalah 1. Publikasi, 2. Event, 3. Keterlibatan Komunikasi, 4. Lobi atau Negosiasi, 5. Social Responsibility (tanggung jawab sosial).

Muhammad Yazid Arif merupakan merupakan petugas Public Relations sekaligus manager di PT. Siar Tour Medan, tanggapan yang diberikan informan ini mengenai strategi komunikasi apa yang digunakan perusahaan untuk mendapatkan citra yang positif dan menadapatkan kepercayaan penuh terhadap calon Jemaah haji dan umroh PT. Siar Tour Medan. Hasil wawancara yang dilakukan terhadap informan kunci adalah membuat suatu iklan dimana iklan tersebut bisa dimedia sosial, kemudian di Koran, dibaliho-baliho atau juga biasanya mereka juga mereka membuat suatu event-event seperti ke daerah-daerah. Kemudian melakukan presentasi dalam rangka menarik minat masyarkat yang ingin mendaftarkan diri menjadi calon Jemaah haji dan umroh PT. Siar Tour Medan, dan menjelaskan paket-paket produk yang ada. Selain itu juga membuat suatu strategi melalui jalur radio yang setiap bulan diadakan di beberapa stasiun 
radio sehingga masyarakat dapat mengenal PT. Siar Tour Medan yang lumayan efektif tanpa harus terjun ke lapangan.

Strategi yang dianggap paling efektif untuk membangun citra yang positif adalah melalui event. Melalui event yang dilakukan diharapkan dapat menimbulkan keinginan masyarakat untuk melihat dan mendaftarkan diri menjai calon Jemaah haji dan umroh. Kemudian yang kedua, melalui radio yang disiarkan secara berulang-ulang diharapkan ingatan masyarakat terhadap perusahaan dapat melekat. Dengan melalui berbagai strategi komunikasi yang dilakukan dapat membangun citra dan kepercayaan, karena setiap tahunnya jumlah calon haji dan umroh terus meningkat. Strategi yang diterapkan SIar Tour cukup efektif dalam memperoleh citra dan kepercayaan dari calon Jemaah haji dan umroh dilihat dari data Jemaah pertahun yang tidak kurang dari 1000 orang dari 2012 sampai 2017. Perolehan jumlah Jemaah siar Tour di 2012 tercata 1.293 orang, 2013 tercatat 1314 orang, 2014 tercatat 1.519 orang, dan 2015 tercatat 1.441 orang, 2016 tercatat 1.505 orang, dan 2017 tercatat 1.830 orang. Selain dari paket regular keberangkatan tersebut juga dari paket yang beragam, seperti paket plus istanmbul, plus ramadhan, paket plus dubai, paket umroh plus turki dan paket lainnya., dengan rata-rata lima kali kebernagkatan rutin setiap bulannya.

Adapun kendala yang ditemui oleh perusahaan PT. Siar Tour Medan dalam melakukan strategi komunikasi oleh Public Relations dibagi dalam dua jenis, yaitu kendala internal dan kendala eksternal. Kendala internal seperti masih digunakannya cara lama dalam melakukan publikasi seperti pembagian brosur, majalah, dan Koran. Padahal di era teknologi saat ini perlu ditingkatkan kearah yang lebih canggih dengan pemanfaatan teknologi. Namun hal ini masih terkendala masalah anggaran biaya. Sementara kendala eksternal, salah satunya adalah banyak perusahaan pesaing sejenis sehingga terpaksa berkompetisi lebih ekstra dan kerja keras untuk menarik minat masyarakat.

\section{SIMPULAN}

Berdasarkan hasil penelitian yang telah dikemukakan, maka dapat iambil kesimpulan strategi Public Relations PT. Siar Tour Medan yang diterapkan cukup efektif dalam memperoleh citra dan kepercayaan dari calon Jemaah haji dan umroh dengan melakukan strategi komunikasi yang efektif sehingga calon Jemaah yakin dan percaya bahwa travel Siar Tour dapat menjadi pilihan bagi calon Jemaah untuk berangkat ke tanah suci.

\section{DAFTAR PUSTAKA}

Effendi. M.W. Hendra. Y. \& Armansyah, M. (2019). Persepsi Masyarakat Tentang Citra Pemerintah Kota Medan Melalui Akun Media Sosial Instagram Study Deskriptif Kualitatif Pada Masyarakat Kota Medan yang Mengikuti Akun Media Sosial Instagram @humas_pemkomedan. PERSPEKTIF, 8 (1): 20-26.

Kotler, P., \& Armstrong, G. (2008). Prinsip-Prinsip Pemasaran Edisi 12 Jilid 1. Jakarta: Erlangga.

Nova, F. (2009). Crisis Public Relations (Bagaimana PR Menangani Krisis Perusahaan). Jakarta: Grasindo.

Panggabean. T.T.N (2019). Strategi Komunikasi Verbal dan Nonverbal Guru terhadap Anak Didik Autis di Yayasan Tali Kasih Medan. Jurnal Simbolika: Research and Learning in Comunication Study. 5 (1): 44-58

Sembiring, J.P., (2016), Strategi Komunikasi Pemasaran Objek Wisata Gundaling dan Pemandian Air Panas Semangat Gunung, Jurnal Simbolika: Research and Learning in Comunication Study, 2 (1): 134-155 
Siahaan, W.C. Hendra, Y. \& Matondang, A (2017). Strategi Komunikasi Pemasaran PT. OPPO Indonesia dalam Meningkatkan Citra Smartphone OPPO. PERSPEKTIF, 6 (1): 8-12.

Siahaan, W.C. Hendra, Y. \& Matondang, A (2017). Strategi Komunikasi Pemasaran PT. OPPO Indonesia dalam Meningkatkan Citra Smartphone OPPO. PERSPEKTIF, 6 (1): 8-12.

Silalahi, U. (2009). Metode Penelitian Sosial. Bandung: PT.Refika Aditama.

Sugiyono. (2006). Metode Penelitian Kuantitatif, Kualitatif, dan R\&D. Bandung: Alfabeta.

Syahputra, D.I. Hendra, Y. \& Hidayat, T.W. (2018). Peran Humas Dalam Membangun Citra Pemerintahan Sumatera Utara Pada Kantor Biro Humas Gubernur. PERSPEKTIF, 7 (1): 24-29

Ritonga, S.A. dan Hasibuan, E.J, (2016), Komunikasi Interpersonal Guru dan Siswa dalam Mengembangkan Bakat dan Kreativitas Anak Autis di SLB Taman Pendidikan Islam (TPI) Medan, Jurnal Simbolika: Research and Learning in Comunication Study. 2 (2): 188-199

Waridah, (2016), Berkomunikasi Dengan Berbahasa Yang Efektif dapat Meningkatkan Kinerja, Jurnal Simbolika: Research and Learning in Comunication Study. 2 (2): 231-239

Hasibuan, E.J, \& Muda I, (2017) Komunikasi Antar Budaya pada Etnis Gayo dengan Etnis Jawa, Jurnal Simbolika: Research and Learning in Comunication Study, 3 (2): 106-113 